\title{
Differentiated Reading Instruction With Technology for Advanced Middle School Students' Reading Achievement
}

\author{
Clarissa Haymon, EdD \\ Walden University, Minneapolis, Minnesota, United States \\ iD https://orcid.org/0000-0002-7263-3996 \\ Andrea Wilson, $\mathrm{PhD}$ \\ Walden University, Minneapolis, Minnesota, United States \\ iD https://orcid.org/0000-0002-1471-654X
}

Contact: clarissa.haymon@gmail.com

\begin{abstract}
Guided by the theory of differentiated instruction, this quantitative study evaluated the effectiveness of Achieve 3000, a technology-enhanced program for differentiating reading instruction. Achieve 3000 was fully implemented with fidelity in a local middle school that has a large percentage of advanced learners. Archived reading scores of 120 advanced Grade 6-8 students were compared pre- and postimplementation of Achieve 3000. A paired-samples $t$ test examining the overall effect of the intervention indicated that students' posttest LevelSet Lexile reading scores were significantly higher than their pretest scores. A mixed-design analysis of variance was used to examine the main and interaction effects of time (pretest vs. posttest) and grade level (Grades 6-8) on students' LevelSet Lexile reading scores. A significant main effect of grade level and a significant time by grade interaction were present with Grade 6 advanced learners showing significantly greater increases in LevelSet Lexile reading scores following the Achieve 3000 intervention as compared to the other grade levels. These findings suggest that the Achieve 3000 program was effective for meeting the specialized differentiated instructional needs of advanced learners in reading. The implications for social change include offering educators viable, technology-enhanced options for effectively differentiating reading instruction for advanced learners resulting in enhanced academic achievement, thereby benefiting students and the school community.
\end{abstract}

Keywords: middle school; content-area literacy; literacy; professional development

Date Submitted: July 10, 2019 | Date Published: May 8, 2020

\section{Recommended Citation}

Haymon, C., \& Wilson, A. (2020). Differentiated reading instruction with technology for advanced middle school students' reading achievement. Journal of Educational Research and Practice, 10, 70-89. https://doi.org/10.5590/JERAP.2020.10.1.05 


\section{Introduction}

With numerous educational policies and accountability models, there has been more examination of influences on student learning in public education (Coleman et al., 2018; Goddard et al., 2015). Education leaders and researchers continue to search for ways to resolve the systemic national decline in academic performance (Coleman et al., 2018; Farrington et al., 2012). Specifically, leaders in public education have recommended that schools focus on increasing math and reading skills. The establishment of the No Child Left Behind (NCLB) Act in 2002 resulted in a focus on struggling learners; however, an unintended consequence of this focus was a lessened emphasis on advanced learners (Jennings \& Lauen, 2016; Monks, 2014). With the introduction of the Every Student Succeeds Act (ESSA) in 2015, the testing requirements established under NCLB remained with an even greater accountability falling to the local districts and states (Darrow, 2016).

In the early 2000s, the U.S. government recognized that there were educational disparities and mandated that by $2014,100 \%$ of all students in public education be required to score proficient in both reading and math (U.S. Department of Education, 2011). Yet, the 2015 National Assessment of Education Progress (NAEP, 2017) assessment results revealed that $66 \%$ of Grade 8 students failed to reach that mark. Additionally, the national school report card indicated that only $34 \%$ of all Grade 8 students attained the "at or above proficiency" mark on the NAEP (2017) reading assessment. With the stipulation of proficiency for all students established by federal law, the focus continues to be placed on the needs of struggling learners while the unique needs of high achieving students are largely ignored. In conjunction with the need to focus on struggling learners, public education should remain conscious of the needs of advanced learners, and research should be conducted to identify educational implications for this unique subgroup.

\section{Reading Achievement in Tennessee}

A review of reading achievement conducted by the National Center of Educational Statistics revealed that in 2010 average reading scale scores and percentages for Grade 8 students in Tennessee's public schools ranked below the national average for proficiency levels for Grade 8 reading students on state achievement tests. This disturbing trend in lower than the national average scores continues for students in Tennessee to this day (National Center of Educational Statistics, 2019). Other education reports for the state of Tennessee revealed that the reading scores of Grade 8 students categorized as "proficient" and "advanced" were only one to two points above the national average (NAEP, 2015, 2017). Additionally, overall average reading scores for Grade 8 students in the state of Tennessee remained at the same levels in 2017 as they were in 2015 and 2013 (NAEP, 2015, 2017). However, annual state achievement scores during this time period revealed an increase in math, science, and social studies scores, yet there continued to be a decline or stagnation in reading (Tennessee Department of Education, 2017). As a result of these declining and stagnating scores in Tennessee, quality instruction and technology integration surfaced as two of the most significant goals established in response to the requirements of being an American Recovery and Reinvestment Act Race to the Top recipient. Thus, in attempting to focus on differentiated instruction through the integration of technology, Tennessee schools became poised to address the gap in performance for its total population of students including its advanced learners.

\section{Gifted and Advanced Learners}

Statistics show that there are approximately 3.3 million children in U.S. schools who are identified as gifted or talented with another 3.6 million children who qualify based on aptitude but are not identified or being served (Dreilinger, 2019). It has been long known that despite the number of students who are identified and receiving services, an insufficient number of these students experience education instruction that helps develop their full educational and psychological advancement potential (Anaya, 2014; Siegle \& McCoach, 
2018). Research shows that when the needs of advanced learners are not addressed the chances of academic completion and success decrease for these students (Center for Comprehensive School Reform and Achievement, 2008; Siegle \& McCoach, 2018; Sparks, 2019). A disappearing gap between advanced and underachieving students may indicate that the needs of advanced students for growth and development are insufficiently addressed (Cleaver, 2008; Siegle \& McCoach, 2018). Existing reforms and supplemental services for struggling learners have not been designed to meet the needs of the broader educational system and especially needs specific to advanced learners (Jennings, 2012; Sparks, 2019). Therefore, by providing differentiated instruction that allows students to progress at their individualized instructional levels, there is an opportunity for advanced academic achievement for all students including advanced learners (Azzam, 2016; Sparks, 2019; Tennessee Department of Education, 2017, 2018).

Increasing the quality of education for all learners can assist in improving the nation's status as a world leader (Coleman et al., 2018; Hanushek \& Woessmann, 2012); however, public education, especially in Tennessee, lacks consistent reading advancement on state tests. Dr. Candice McQueen, now former Tennessee Commissioner of Education, described the stagnating reading performance as an ethical and moral dilemma (Tatter, 2015). These subpar performance outcomes have consequences for both students and school systems. Therefore, the U.S. Department of Education has been promoting federal initiatives to investigate higher order reading activities to improve comprehension skills.

Despite demands for educational reform, high stakes testing does not ensure accountability, and America does not appear to nurture advanced learners (Finn \& Wright, 2015). Additionally, when considering prior implications of NCLB and now ESSA, public school systems possess little motivation to ensure the highest learners are encouraged to acquire the highest level of academic potential (Finn \& Wright, 2015). Further, those students deemed to be advanced learners are often the group most challenged to show performance gains due to their already high assessment scores. Although the nation has transitioned to ESSA era, the institutional capacities continue to struggle (McGuinn, 2015). Furthermore, evidence suggests that public school systems have not only neglected advanced learners but have also cut funding of programs and projects for these learners (Dreilinger, 2019; NAEP, 2017; Sparks, 2019). Current educational practices are insufficient in adhering to the various skillsets and learning profiles of students while abiding by program practices and expectations (Callahan et al., 2015). The inability of schools to offer diversified instruction that meets the needs of all learners-struggling, proficient, and advanced-magnifies the individualized instructional challenge (Wan, 2016).

\section{Literature Review}

\section{Academic Needs of Advanced Learners}

Advanced learners are a valuable commodity in need of educational resources dedicated to moving this population upward with the core goal of negating the trend of remaining disengaged from school (Dreilinger, 2019; Esparza et al., 2014; Siegle \& McCoach, 2018). Too many advanced learners are plagued by underachievement in the modern classroom. Underachievement, defined as an inconsistency in instructional outcomes between academic performance and ability, surfaces as a common thread of concern with regard to the subgroup of advanced learners (Karaduman, 2013; Siegle \& McCoach, 2018). Overall, there are societal implications and consequences when such students are not reaching their full potential (Dreilinger, 2019; Esparza et al., 2014). A few factors that may be contributing to underachievement include lack of differentiated instruction, lack of individualized learning opportunities, and lack of quality instruction reaching the academic needs of these students (Karaduman, 2013; Siegle \& McCoach, 2018; Sparks, 2019). While there is a strong transition across the nation toward embedding common standards into the curriculum 
richly, even such standards remain insufficient regarding the task of challenging the most advanced learners (Ash, 2013; Azzam, 2016).

Various factors may contribute to the underachievement and lack of significant academic growth in reading for advanced learners. Learners in the 21st-century strive to independently pursue learning in knowledgecentered, contemporary classrooms (Tomlinson, 2015). Thus, educators must help students identify their unique talents, then create situations where they can be successful. Students come with an innate curiosity that needs to be cultivated in a way that promotes further learning and academic development. This promotion of learning occurs when the environment is solidified in quality instructional standards and clearly assigned tasks that allow for differences that are not only accepted but well expected (Doubet \& Hockett, 2016).

Additionally, students' lack of interest and effort tends to be connected to a lack of the differentiation that is necessary to meet students' learning needs in reading, especially in the advanced learner population (Little et al., 2014; Sparks, 2019; Yuen et al., 2016). A survey of elementary and secondary students revealed that students prefer instructors who spend less time in direct whole-group lecture, address students' specific learning needs, individualize instruction, offer choice, and establish interest through quality questions (Doubet \& Hockett, 2016). Classroom environments focused on choice, individuation, and inspiring interest are necessary for continual success among the highest achieving students (Azzam, 2016; Sparks, 2019; Watts et al., 2012), which can allow them to work as productive and ethical members of society (Thompson et al., 2010).

\section{Maslow's Hierarchy of Needs in the Classroom}

Abraham Maslow's theory on the hierarchy of needs can be used to exemplify how students' needs can direct educational organization and apply uniquely to the advanced learner (Burleson \& Thoron, 2014; McLeod, 2017). For instance, the educational system is expected to analyze and address its deficiencies to help students with individualized success. In Maslow's (1943) hierarchy of needs, various types of deficits can be analyzed to help magnify pathways to individualized actualization and educational success. When there is a plan for creating a school culture with instruction that is personalized and learning that is interest-driven, students feel safe, secure, and supported through quality resources to pursue self-fulfillment in learning, which often results in maximizing achievement (Chametzky, 2014).

Using "basic needs" from Maslow's (1943) hierarchy of needs, there is an initial point of student motivation with correlation to stress levels, safety, and security. Considering the basic and higher needs of advanced learners is mandatory to extend beyond the conventional curriculum of today's realm of education (Bannister, 2016). The key is understanding that each student is to be viewed as a valuable learner worthy of challenging work; in grasping this, learners are thereby able to thrive (Bannister, 2016). Learners are better able to retain information longer and greater with more internalization when learning is diversified and thereby individualized (Joseph et al., 2013). Furthermore, growth and development occur when students are allowed to embrace their uniqueness in the school setting (Azzam, 2016; Yacapsin, 2013). There is an individualized component to each adolescent, and the role of public education is to empower all learners, collectively and as individuals (Podgurski, 2016). Therefore, differentiated instruction can be useful in addressing the various academic needs of all students, especially for fostering the unique instructional needs of advanced learners (Azzam, 2016; Botty \& Shahrill, 2014; Yuen et al., 2016).

Additionally, although a teacher may not be able to meet students' everyday basic needs beyond limited school-based programs, there are many other avenues to consider in addressing students' needs via the classroom (Burleson \& Thoron, 2014). A teacher's willingness to open the classroom structure to differentiated instruction allows for the opportunity to reach the multifaceted learning needs of each student 
while demonstrating the motivation to see all learners succeed (Azam, 2016; Jesus, 2012; Yuen et al., 2016). A teacher developing instruction to fit the needs of all students includes adapting materials, modifying the content, incorporating projects, and implementing quality assessments, which all provide learners with opportunities for creativity, fulfillment, and achievement (Azzam, 2016; Jesus, 2012). Furthermore, students seek and establish quality relationships with their instructors.

By embracing students' individual differences, positive interactions and strong interpersonal relationships between students and teachers are solidified (Yacapsin, 2013). In consideration of Maslow's (1943) selfesteem need, there is the charge for educators to demonstrate the commitment to students in pursuit of academic achievement and accomplishment (Burleson \& Thoron, 2014; Yacapsin, 2013). Consistent with Maslow's self-actualization need there is an understanding that when learners are not allowed to explore their gifts, talents, and areas of interest, optimal success and satisfaction are negated (Burleson \& Thoron, 2014; Maslow, 1943). The positive attributes and behaviors that are evident at increasingly higher levels of Maslow's hierarchy of needs may be allowed to materialize in classrooms where differentiated instruction is in the forefront.

\section{Student Empowerment via Individualized Instruction}

Understanding students' individual personal and instructional needs while fostering interest and ability is a significant contributor to student success (Bates et al., 2016; Sparks, 2019). Teachers of advanced learners may struggle with a lack of support, knowledge, and resources that are required to educate this population of students (Dimitriadis, 2016; VanTassel-Baska \& Stambaugh, 2012). For Tennessee, 85\% of school funding is tied to performance outcomes, including the number of students completing courses, credentials, and degrees (Pratt, 2017). Thus, reaching and exceeding academic expectations at elementary and middle school grade levels are significant in preparing students for a successful transition to high school and postsecondary success.

Students' struggles with reading comprehension potentially are due to a lack of individualized reading instruction that adheres to academic needs while remaining commensurate with individual reading levels over time (Wijekumar et al., 2017). For example, McCarty and colleagues (2016) explained that not only do students fail to stay engaged when the instruction is not relevant, but dropout rates increase when instruction is lacking in quality and individuation. Instruction promotes student success when the instruction is delivered with rigorous and relevant lessons (Callaway, 2015).

Present and future classrooms require innovative strategies for student empowerment to maximize success (Van Wyk, 2017). One practical way of reaching the diverse needs of learners, especially advanced learners, is through the implementation of online learning platforms (Dimitriadou et al., 2012). Web-based reading instruction provides a supplement to the curriculum while allowing for differentiated activities and comprehension support (Wijekumar et al., 2017).

Although there has been disagreement in public education circles regarding what constitutes quality instruction for all learners, researchers and policymakers are exploring quality teaching practices like Bill and Melinda Gates' Measures of Effective Teaching for reaching all learners' individual academic needs (Conklin, 2014). Educational practices are developing to maximize learning by modifying teaching methods to meet students where they are and move them to where they need to be (Nicolae, 2014). It is important to enhance individualized reading instruction by providing opportunities to explore leveled text, match online instruction to the needs of middle school readers, and examine digital components that support diversified academic growth in the general classroom setting (Bates et al., 2016). Consequently, differentiated instructional approaches have received attention as a possible strategy to mitigate reading deficiencies and enhance reading skills in all student populations at all grade levels, middle school included. 


\section{Innovative Instruction Using Differentiation in Reading}

Pioneering innovations in instruction can be the primary antidote to move students beyond the current condition of stagnant reading achievement that has become the norm in middle-grades and secondary education (González, 2017). Although students in elementary settings are making progress consistently, the same level of progress is not evident overall in middle and secondary school settings (Cantrell et al., 2016). Interestingly, elementary teachers tend to be more intentional with differentiated instruction, but older students do not have the same instructional opportunities as frequently (Doubet \& Hockett, 2017). Critical reading skills, as indicated by college readiness, constitute disciplinary literacy and having a skillset for reading text that differs from that of secondary education; therefore, appropriate strategies for textual engagement and curricular enhancement are fundamental (But et al., 2017). Furthermore, college students continue to need sufficient access to quality text-based reading material, a setting conducive to time being devoted to individualized reading, and overall support from all invested stakeholders (Flink, 2017).

Consistent, intentional instruction that devotes time to high quality reading programs, individualized learning, and computer-assisted instruction is necessary in today's classroom (Cantrell et al., 2016). Students need increased exposure to and practice with individually appropriate text complexity to build stamina and avoid stagnation, which also correlates to learners' academic advancement (Fisher \& Frey, 2016). However, it is important to determine how to get and keep readers improving their skills (Fisher \& Frey, 2016). In a typical classroom setting, conventional instruction tends to be most beneficial for average learners; whereas, other learners gain advantages from computer-based reading instruction when such computer-driven instruction includes clear, consistent lessons with leveled enhancement and informational text (Fenty et al., 2015). Contrary to traditional, routine reading lessons, various types of reading support adhere to individualized students' instructional needs and yield academic growth as well as reading advancement (Fisher \& Frey, 2016). For instance, Day (2015) found that extensive reading progress emanates from a variety of reading material with text selection based on interest and reading level with an individualized approach for skill development.

Differentiated instruction helps meet the academic needs of diverse learners (Tomlinson, 2015). According to a recent study, differentiated instructional practices solidified student engagement in classroom instruction, improved participation in lesson activities, and increased learning of skills and concepts (Duquette, 2016). The basic principles of differentiated instruction include assisting students to learn by connecting interests, experiences, and curriculum. Lack of autonomy and individuation in school produces a lack of motivation and thereby, inhibits academic progress (Hobbs \& Dofs, 2017). Students should be empowered to understand how they learn as individuals through acquisition of strategies and experiencing opportunities for success, either collectively or independently (Hobbs \& Dofs, 2017). This empowering approach further benefits advanced learners because they can be motivated beyond their academic level of comfort with differentiated strategies. One way to ensure that instruction reaches advanced learners is by practicing a tiered model given its ability to enhance students' interest, engagement, and individual skill sets (Aliakbari \& Haghighi, 2014; Azzam, 2016).

It is relevant to explore the need to find an appropriate way of evaluating achievement gains through autonomous learning (Hobbs \& Dofs, 2017). Analyzing the process by which students facilitate their individualized learning is a recurring educational exploration. Also, students encompass diverse levels, backgrounds, interests, and instructional needs while they are expected to master the same grade-level standards (Siam \& Al-Natour, 2016). Recent research shows how the development of strategies can be made more accessible by integrating technology for the use in independent, autonomous learning (Yot-Domínguez \& Marcelo, 2017). As such, computer-based instruction implemented in conjunction with the general 
curriculum seems to be a vital resource to enhance quality instruction aimed at reaching all learners (Cook, 2005; Yang et al., 2018).

Differentiated instruction more richly engages students in their learning, provides for constant growth and development, and allows for a stimulating and exciting classroom (Azzam, 2016; Fenty, et al., 2015; WattsTaffe et al., 2012). Peer intervention is an example of differentiated instruction that can be achieved by offering suggestions for peer assistance, including tutoring experiences, small group sessions, and dialogue experiences (Azzam, 2016; Nguyen, 2013). Such peer-driven practices are effective, especially with advanced learners, because they provide meaning and understanding that is acquired from sharing and learning with peers. Furthermore, in the development of reading skills, Nichols et al. (2008) concluded that collaboration promotes vocabulary because communicating vocabulary with peers brings print to life and facilitates interactive reading and discussion to improve vocabulary skills. Indeed, when looking to inspire and challenge learners, using quality teacher-student and peer-peer communication and questioning techniques are found to be beneficial (Gray, 2012; Yang et al., 2018).

\section{Technology in the Differentiated Reading Classroom}

When there is higher engagement with reading instruction, the subsequent outcome is higher reading achievement (Laverick, 2014; Yang et al., 2018). It is a reasonable expectation that modern teachers appropriately amend instruction based on learners' academic inclinations, interests, and profile to maximize engagement (Dimitriadis, 2016; Joseph et al., 2013). Some indicate that differentiated instruction and technological components are essential in designing engaging instruction for all students and to avoid the pitfall of neglecting the advanced learner (Dimitriadis, 2016; Stack, 2015). Technology-enhanced teaching techniques yield positive instruction and assessment support in several ways, from family access to resources to ongoing learning with engagement (Laverick, 2014; Yang et al., 2018).

Based on existing theory and research in this area, teachers are expected to consistently and vigorously address curriculum and instruction in response to student readiness, learning profile, engagement, and interest (Tomlinson, 2015). Interest in reading is acquired through choice, which promotes further reading and exploration that branches out into other core subjects like science and history. The students' established interest continues to broaden their vocabulary, background knowledge, and curiosity leading to enhanced comprehension (Whitten et al., 2016). Additionally, the incorporation of technology to heighten the instructional content presented in a traditional classroom setting can provide a fresh approach to achieving the learning goal of enhancing reading comprehension skills (Chen \& Herron, 2014; Yang et al., 2018); technology integration tends to allow for a more enjoyable learning experience for today's students (Ochoa \& Ramriez, 2016). Furthermore, Ness (2017) found that students are requesting more technology integration to help make reading instruction more engaging.

Even in today's realm of public education, reading remains the most elusive and fundamental instructional skill students must master (Keyes et al., 2017). Today's practitioners hold the essential task of continuously helping students grow as critical thinkers and readers (McElhone, 2015). The process of allowing students to diversify their learning through technology integration promotes critical thinking, reasoning, and other valuable skills. Time management, choice, interest, and instructional expectations are essential elements of learning that students must consider and navigate while working independently in a technology-rich environment to accomplish their learning goals (Ochao \& Ramriez, 2016; Yang et al., 2018).

Moreover, there is a real possibility of increasing reading achievement by equipping teachers with efficient technology and professional development for proper usage to help further promote reading comprehension (Keyes et al., 2017). While there are numerous opportunities for technological developments regarding reading comprehension, technology-supported feedback and instruction are next-level demands (Pascual \& 
Guevara, 2017). There is a necessary instructional component for utilizing class time to teach, model, and practice the current reality of reading digital text (Saldana, 2013; Yang et al., 2018). There is a strong charge from those invested in public education to continue navigating beyond traditional class settings and standards that rely on rote and scripted practices (Ash, 2013). It is pivotal for teachers' instructional stances to prioritize progressive instructional effectiveness (McElhone, 2015). Enhancing classroom practices with digital means immediately allows for the ready incorporation of authentic literature with a rich diversity in the text in the modern reading classroom (Möller \& Ferguson, 2015; Yang et al., 2018).

In considering alternative instructional methods for the reading classroom, Pascual and Guevara (2017) found that by using automated reading technology, students made positive strides in reading comprehension. For example, allowing students to discover their areas of needed reading improvement, as opposed to teachersuggested improvements, is shown to be an effective strategy for increasing reading proficiency (Laverick, 2014). Further, while students are allowed the opportunity to read aloud regularly in the traditional classroom, seldom are they able to reflect on where they are and how they are progressing as individual readers. Therefore, the incorporation of video recording capacities via technology provides a means for students to review and manage their own progress that is not available otherwise (Ness, 2017). The ability to provide a greater array of text choice, increased opportunity to interact with text in various modes, and more time to explore targeted diverse literature are promising aspects of digital learning with regard to promoting reading comprehension for today's learners (Möller \& Ferguson, 2015; Yang et al., 2018).

Unfortunately, there are aspects of the traditional classroom settings that hold a tendency to resist change (McElhone, 2015). Opportunities for individualized exploration, growth, and progress tend to be more limited in the traditional classroom setting. Ochao and Ramriez (2016) shared that while significant benefits exist for instructional technologies, obstacles are present when technology infrastructures and supports fail, teachers are not provided with adequate training on proper use and implementation of the technological resources, systems maintain the use of outdated worksheets and workbooks, or there continues to be an overreliance on a teacher-centered approaches. It is important to note the need for schools to maintain consistent technology availability, access, and support when navigating the trend of technology integration in the traditional classroom setting in order for solid reading comprehension instructional practices to develop (Möller \& Ferguson, 2015; Yang et al., 2018).

Considering the expanded expectations of today's learners, college and career readiness constitutes an ability to not only read but also comprehend a range of texts, including informational texts across content areas independently and proficiently (Ritchey et al., 2017). While reading comprehension remains a critical component of the reading process, today's learners can experience struggles with comprehension, and teachers often experience difficulty in securing strong reading comprehension skills in their students via their teaching methods (Klapwijk, 2015). The ultimate result of quality education is self-actualization that entails realizing personal potential and owning personal growth. Using differentiated instruction with technology integration allows students to remain aware and to take ownership of their individualized learning and reading progression.

\section{Purpose of the Study}

The problem being investigated in this study was that a significant proportion of middle school students who score advanced in reading were either stagnant or decreasing in percentiles on the annual Tennessee state reading assessments in this research setting. In an effort to mitigate this problem, the middle school implemented the Achieve 3000 technology-based reading instruction program but did not conduct a formal analysis of the program's effectiveness. Thus, there was a need to investigate implications of the Achieve 3000 program for its capacity to address the lack of reading growth for advanced learners. The purpose of this 
quantitative analysis of the Achieve 3000 program was to determine the effectiveness of differentiated instructional practices with the use of technology on Lexile growth reading scores for advanced Grade 6-8 students. The following research questions guided this study:

Research Question 1: Does the method of technology-enhanced differentiated instruction through Achieve 3000 impact Lexile growth reading scores for advanced sixth- through eighth-grade students?

Research Question 2: Does Lexile growth differ by grade for sixth- through eighth-grade learners in technology-enhanced differentiated instruction through the implementation of Achieve 3000 ?

\section{Method}

\section{Research Design and Approach}

A quantitative research approach was employed for the current program analysis. The variables in this study included the independent variables of time (pre vs. postimplementation of Achieve 3000) and grade (Grades 6-8). The dependent variable was Lexile reading levels as determined by a universal screener of nonfiction reading. The Achieve 3000 LevelSet represents the universal screener that measures reading comprehension of nonfiction text and formulates Lexile level (0-1600) based on correct responses (Achieve 3000, 2017). Lexile level scores encompass various reading skills including those in the analysis and comprehension of literature, understanding the complexity of informational text, and acquired vocabulary usage. Expected annual Lexile growth for students in Grades 6-8 ranges from 75 to 100 points in reading (Achieve 3000, 2017).

An ex post facto, quasi-experimental research design with a pretest-posttest comparison was employed for this study. The comparison for this study included Achieve 3000 Lexile scores from September 2017 to June 2018 to identify student progress. To enhance the validity of the results and identify any possible test-retest practice effects within the sample, the Achieve 3000 LevelSet assessment was carefully inspected. This inspection found that, although the same group of students saw the pre-/postassessment, the questions and passages were different for the pre-/postassessment, and the questions and passages seen by each student were determined by each individual's Lexile change over time. This assessment met the requirements for acceptable analysis of the Achieve 3000 program in this setting. In summary, the current analysis was intended to determine the effectiveness of differentiated instructional practices with the use of technology on Lexile growth reading scores for advanced Grade 6-8 learners.

\section{Setting and Sample}

The population consisted of 120 total advanced learners for Grade 6-8 at one Tennessee middle school where Achieve 3000 was fully implemented ( $n=39$ from Grade 6, $n=42$ from Grade 7, and $n=39$ from Grade 8). These advanced learners were recognized as advanced in correlation to STAR data and the state achievement test's criteria for cut scores of the four brackets: advanced, proficient, basic, and below basic. Post hoc power analysis determined the achieved effect size for the sample was 1.03, and the achieved power was 1.00.

The study occurred within the context of the advanced learners' language arts classes; the final sample was determined by the total number of advanced learners by grade. There were four language arts teachers per grade level. Each grade level teacher had four classes. Each teacher had a classroom composition inclusive of average and advanced learners; however, only the advanced learners were included in the sample for this study. In this setting, middle school Language Arts classes operated on an hourly schedule with 60-min language arts classes five times per week. During the full period of the study, teachers were responsible for 
classroom instruction based on state standards and district curriculum with the inclusion of Achieve 3000 in their regular weekly activities. All classroom teachers were offered guidance and training on the Achieve 3000 program expectations, guidelines, timeline, and program dynamics.

\section{Achieve 3000 Implementation}

Achieve 3000 is supported by evidence from experimental and quasi-experimental research studies that is considered in the research community to provide strong and effective substantiation (Achieve 3000, 2017). Achieve 3000 addresses informational reading of nonfiction content beginning at the student's identified instructional level. In addition to the program's basic technology-driven instruction that is designed to meet students at their current reading level, the Achieve 3000 program incorporates stretch articles aimed two grade levels above individual Lexile levels including cross-curriculum informational text and vocabulary paired with writing platforms to address academic need and progression within various reading Lexile levels (Achieve 3000, 2017).

The Achieve 3000 program tracks growth in student achievement through a meta-metrics system employed to determine and track Lexile reading levels (Achieve 3000, 2017). The program enables teachers to individualize reading instruction by monitoring each student's progress, individual goals, and confidence (McLean, 2012). A key claim of the Achieve 3000 program is that advanced learners excel with the technology-enhanced online platform which provides challenging text at individualized levels to maximize significant reading performance (Achieve 3000, 2017). Although the Achieve 3000 program claims to have the instructional capacity to address advanced learners via its components, a thorough analysis of the program was needed to review such implications for this population and setting.

All identified students completed the Achieve 3000 LevelSet assessment early in the first semester (pretest) and then again at the end of the second semester (posttest). Data used in this study were filtered to include only the students completing assessments at both testing intervals; those students not completing both assessments were excluded from the final sample. During the period of program implementation, students were given $4 \mathrm{hr}$ of class time per month for the duration of the academic school year to work with the Achieve 3000 program. All students were provided access to computer use and Achieve 3000 required online materials during this time.

\section{Results}

Regarding Research Question 1, the first step was to determine the descriptive statistics for the entire sample of Grade 6-8 students, including the mean and standard deviation of the Lexile scores on both the pre- and posttest. The total original sample included 120 students $(n=39$ from Grade 6, $n=42$ from Grade 7 , and $n=$ 39 from Grade 8), all with pretest and posttest LevelSet Lexile scores. On the pretest, the scores for the entire sample ranged from 785 to 1,595 with a mean of $1,307.67(S D=147.82)$. On the posttest, the scores for the entire sample ranged from 1,105 to 1,600 with a mean of $1,492.67(S D=102.87)$. Students increased their Lexile scores on the posttest by 185 points. The Achieve 3000 program currently maxes out at 1,600 Lexile level. The findings show that a few students were able to reach this maximum capacity. A paired-samples $t$ test was used to determine whether the difference between the pretest and posttest mean scores was statistically significant. The results of the $t$ test demonstrated that the difference was statistically significant $(t=18.69, d f$ $=119, p=.000)$. Thus, the students performed significantly higher on the posttest.

However, further analysis of the individual scores demonstrated that the lowest score on the pretest and posttest (785 and 1,105, respectively) belonged to the same advanced student who was in Grade 8 . This single, uncharacteristically low score appeared to be an outlier as it was nearly four standard deviations below the 
mean on both the pretest and posttest for this advanced student. Thus, the analyses were rerun without the outlier's scores.

Removal of the outlier changed the descriptive statistics of the sample. In particular, it reduced the standard deviation slightly, making the mean a better representation of the sample which was now closer to the normal curve. The total sample without the outlier included 119 students. On the pretest, the scores ranged from 905 to 1,595 with a mean of $1,312.06(S D=140.36)$. On the posttest, the scores ranged from 1,245 to 1,600 with a mean of $1,495.67(S D=96.89)$. Students increased their Lexile scores on the posttest by 183.61 points when the outlier was excluded.

A paired-samples $t$ test was used to determine whether the difference between the pretest and posttest mean scores was statistically significant after the removal of the outlier. The results of the $t$ test without the outlier were very similar to the initial $t$ test. Results demonstrated that the difference was statistically significant $(t=$ $18.55, d f=118, p=.000)$. Thus, it can be safely concluded that the students performed significantly higher on the posttest.

The results for Research Question 2 explore the pretest and posttest results for each of the grade levels over time. To fully address Research Question 2, a mixed-design analysis of variance (ANOVA) analysis was conducted to examine the effects of grade and time, as well as any interaction between these two variables. Specifically, a $2 \times 3$ mixed-design ANOVA was used to unpack further whether grade level had any effect on students' pre-/postintervention Lexile score changes. In keeping with the decision to exclude the single outlier identified previously, analyses were run without the outlier to ensure that the results were not overly influenced by the presence of the uncharacteristically low scores associated with the outlier. The results of the mixed-design ANOVA showed multiple statistically significant results. First, as noted below in Table 1, the main effect of time (pre-post) was significant, $F(1,116)=566.38, p=.000$. Students scored significantly higher following participation in the Achieve 3000 program. The Grade 6 group had a mean gain at 279.88, the Grade 7 group at 125.48 mean gain, and the Grade 8 group had a mean gain of 149.87 .

Table 1. Results of the Mixed-Design Analysis of Variance

\begin{tabular}{lccc}
\hline \multicolumn{1}{c}{ Effect } & $\boldsymbol{F}$ & $\boldsymbol{d} \boldsymbol{f}$ & $\boldsymbol{p}$ \\
\hline Time & 566.38 & 1,116 & .000 \\
Grade & 9.92 & 2,116 & .000 \\
Time $\times$ Grade interaction & 38.04 & 2,116 & .000 \\
\hline
\end{tabular}

Table 1 also shows that the main effect for grade was statistically significant, $F(2,116)=9.92, p=.000$. Tukey's post hoc analysis indicated that the Grade 6 students' posttest scores $(M=1,494.62, S D=93.33)$ were significantly lower than those of Grade $8(M=1,531.58, S D=81.86)$ and that the Grade 7 students' posttest scores $(M=1,464.88, S D=103.59)$ were significantly lower than those of Grade $8(M=1,531.58, S D=81.86)$. The difference between the Grade $6(M=1,494.62, S D=93.33)$ and Grade $7(M=1,464.88, S D=103.59)$ posttest scores was not significant. In addition, as shown in Figure 1, a significant time by grade interaction was present, $F(2,116)=38.04, p=.000$. Students' scores on the posttest depended on the grade they were in, where students in Grade 6 showed greater increases in Lexile score following the intervention than both the students in Grades 7 and 8. 


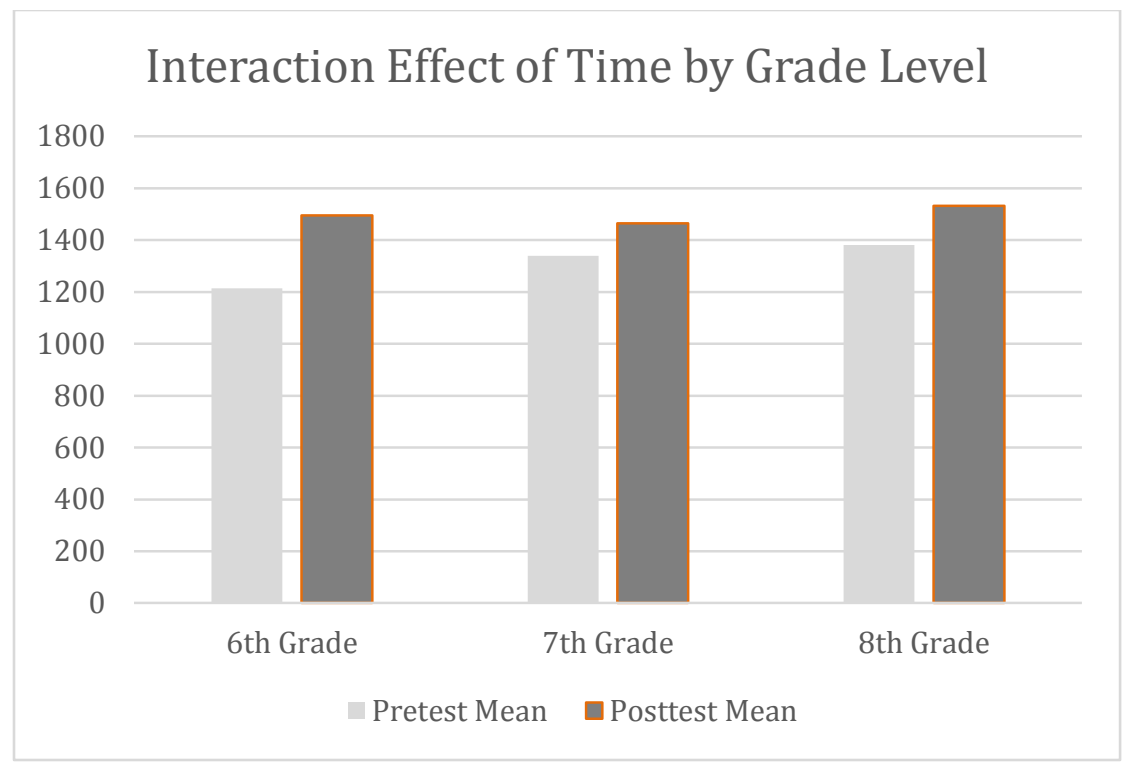

Figure 1. Lexile Score Means Compared by Time and Grade Level

Descriptive statistics were calculated to examine the number of students at each grade level as well as the mean scores for each grade level. Table 2 shows these descriptive statistics. With the outlier removed, each grade level increased in Lexile score from pre- to posttest. Grade 6 students increased the most (279.88 mean gain) while Grade 7 students increased the least (125.48 mean gain). Grade 8 had a mean gain of 149.87 .

Table 2. Number of Students Pre- and Posttest Lexile Scores by Grade Level

\begin{tabular}{cccc}
\hline Grade level & $\boldsymbol{n}$ & Pretest $\boldsymbol{M}(\boldsymbol{S D})$ & Posttest $\boldsymbol{M}(\boldsymbol{S D})$ \\
\hline 6 & 39 & $1,214.74(133.07)$ & $1,494.62(93.33)$ \\
7 & 42 & $1,339.40(129.04)$ & $1,464.88(103.59)$ \\
8 & 38 & $1,381.71(101.88)$ & $1,531.58(81.86)$ \\
\hline
\end{tabular}

A paired-samples $t$ test was used to determine whether the increases in Lexile scores from the pretest to posttest were statistically significant for each grade level after the outlier was removed. The results of the $t$ test included in Table 3 demonstrated that for all three grades, the increase in students' scores following the intervention was statistically significant.

Table 3. Paired-Samples t Test Results of Time (Pretest vs. Posttest) for Each Grade Level

\begin{tabular}{cccc}
\hline Grade level & $\boldsymbol{t}$ & $\boldsymbol{d} \boldsymbol{f}$ & $\boldsymbol{p}$ \\
\hline 6 & 14.41 & 29 & .000 \\
7 & 12.54 & 41 & .000 \\
8 & 17.60 & 36 & .000 \\
\hline
\end{tabular}


The findings reveal the Grade 6-8 students demonstrated measurable progress in Lexile gains, as evidenced by the results of the pre and posttest comparisons. Atlhough it is expected that students will make an average Lexile gain of 75-100 (Achieve 3000, 2017), this outcome shows that as a whole group, these students increased their Lexile levels by an average of 183.61 points, which is far greater than the expected maximum gain of 100 points. These findings also show that, even in the group with the smallest level of growth, Grade 7 advanced learners (mean gain of 125.48 points) outgained the assessment's expected maximum, and the greatest growth with Grade 6 advanced learners at a gain of 279.88 mean points more than doubled the expected maximum gains for the assessment. Overall, these middle school students identified as advanced learners exemplified significant progress following participation in the differentiated, technology-based program of Achieve 3000.

\section{Discussion}

Computer-based instruction can be beneficial in increasing meaningful text interaction and reading progress (Fenty et al., 2015; Yang et al., 2018). The findings of this study of advanced learners at the middle school level using the Achieve 3000 computer-based reading program add further support to the conclusion that computer-based instruction is a viable option for students. Public education is a venue that should facilitate learning, encourage a constant pursuit of knowledge, promote independent learners, and grow digital literacy (Wadmany \& Kliachko, 2014; Yang et al., 2018). Furthermore, society is moving toward globalization, meaning students need skillsets that allow them to analyze, reason, and evaluate (Farrington et al., 2012).

As society continues to become involved in international economies and innovation, the outcomes of literacy are significant (Schatz, 2015). This topic is especially important as struggles with literacy typically persist into adulthood (Rapp et al., 2007). Additionally, reading level is the greatest predictor of acadmic success before, during, and after high school, where there is currently too great a percentage of students lacking in reading proficiency (Bigozzi et al., 2017; Pimentel, 2013). Therefore, this investigation into technology-driven reading achievement strategies for advanced learners was significant to not only the students and parents but also to teachers and the community.

It was necessary to address lack of reading proficiency for advanced students at the middle school level, because $87 \%$ of students report plans to attend college yet less than half of students feel prepared for college success (Leal, 2015). In reviewing American College Test (2017) results, 47\% of high school graduates nationwide met college readiness benchmarks in 2017, yet only $39 \%$ of Tennessee graduates were able to meet that same threshold. By resolving the existing problem with the reading instruction all students and for advanced learners specifically, the possibility of college success increases because these students may become better equipped for future academic challenges.

\section{Directions for Future Research}

Limitations of the study included sample size, instructor variability, and demographics. Although the study primarily focused on the advanced population of each middle school grade level, additional research should be conducted to explore if similar findings emerge for struggling readers in similar school settings. Secondly, the findings show that Grade 6 students experienced the most dramatic growth. Further studies may yield insight into the varying dynamics in grades and instructors with regard to the teaching style and common delivery of instruction. Given the current discovery of the greatest Lexile gain being in these Grade 6 advanced learners, it seems that one additional area of exploration incudes the need for a deeper investigation into the use of technology-driven reading strategies with younger advanced learners. The question remains as to whether reading growth is greater based on grade for other grade levels. 
The overall result of the current investigation shows that the Achieve 3000 program can significantly benefit advanced learners. Additional research should be conducted to review if results are similar for struggling readers and other diverse types of learners. Furthermore, while it was not a factor for the study, subsequent investigations targeting possible benefits for students with other possibly relevant characteristics such as demographics, socioeconomic status, age, disability status, and more should be considered. Understanding the role of economic status, demographic patterns, and cultural barriers are key components that potentially hold the capacity to greatly impact academic success for all students (Sanders, 2017).

\section{Conclusions}

Given that a significant proportion of students who score advanced in reading were either stagnant or decreasing in percentiles on the annual state reading assessments for this particular setting, there was a need to investigate implications of the Achieve 3000 program for its capacity to address issue of lack of reading growth for advanced learners. As exemplified in the body of this research, this particular district was comprised of a substantial number of advanced learners and a lower proportion of struggling readers at the time of the study. The decreasing percentiles on the state reading achievement test for advanced middle school students in this district was noteworthy. By addressing this known issue regarding subpar reading progress with advanced learners, it is possible that improvement can be made to increase reading progress overall and for students in like settings.

The Achieve 3000 differentiated reading instruction program allowed advanced learners in this school the opportunity and resources to individually excel in the area of reading when provided weekly instructional time, as demonstrated by the reported results in this particular setting. Based on the findings, the differentiated computer-based reading program seemed to allow for significant Lexile growth in all of these advanced learners with the Grade 6 students benefitting most of all. Although the Achieve 3000 program initially presented with the ability to help struggling readers grow, these findings confirm the same capacity for advanced learners as well. By focusing on the advanced learner, a pathway of information and interest is piqued for continuous exploration. The results of this study do indicate that the Achieve 3000 program made a statistically significant difference in reading achievement for these learners providing foundational information that can be used to improve reading progress for advanced students even further.

Additionally, in light of this study's significant positive outcomes, relevant information can be used solidify future implementation guidelines for this program and others like it. Ultimately, this study provides a baseline for other schools, districts, and researchers to monitor the competency of technology-driven reading programs in addressing the needs of advanced students in the general education setting. Schools and districts should continue to explore the Achieve 3000 reading program and further implement quality instructional practices to maximize support to advanced students.

\section{References}

Achieve 3000. (2017). Enabling remote learning for every student. http://www.achieve3000.com/

Aliakbari, M., \& Haghighi, J. K. (2014). On the effectiveness of differentiated instruction in the enhancement of Iranian learners reading comprehension in separate gender education. Procedia: Social and Behavioral Sciences, 98(1), 18-189. https://doi.org/10.1016/j.sbspro.2014.03.405

American College Testing. (2017). Tennessee: The condition of college and career readiness 2017. https://www.act.org/content/dam/act/unsecured/documents/cccr2017/Tennessee-CCCR-2017Final.pdf 
Anaya, A. (2014). Differentiated special education for gifted students. US-China Education Review B, 4(11), 781-795.

Ash, K. (2013). Gifted learners: Poised to join the conversation. Education Week, 33-34.

Azzam, A. (2016, April). Six strategies for challenging gifted learners. ASCD Education Update, 58(4). http://www.ascd.org/publications/newsletters/education-update/apr16/vol58/numo4/SixStrategies-for-Challenging-Gifted-Learners.aspx

Bannister, N. (2016). Breaking the spell of differentiated instruction through equity pedagogy and teacher community. Cultural Studies of Science Education, 11, 335-347. https://doi.org/10.1007/s11422-0169766-0

Bates, C., Klein, A., Schubert, B., McGee, L., Anderson, N., Dorn, L., McClure, E., \& Ross, R. (2016). E- books and e-book apps: considerations for beginning reader. Reading Teacher, 70(4), 401-411. https://doi.org/10.1002/trtr.1543

Bigozzi, L., Tarchi, C., Vagnoli, L., Valente, E., \& Pinto, G. (2017). Reading fluency as a predictor of school outcomes across grades 4-9. Frontiers in Psychology, 8(200), 1-9. https://doi.org/10.3389/fpsyg.2017.00200

Botty, H. M. R. H., \& Shahrill, M. (2014). The impact of Gagné, Vygotsky and Skinner theories in pedagogical practices of mathematics teachers in Brunei Darussalam. Review of European Studies, 6(4), 100109.

Burleson, S. E., \& Thoron, A. C. (2014). Maslow's hierarchy of needs and its relation to learning and achievement. http://edis.ifas.ufl.edu/wc159

But, J. C., Brown, P., \& Smyth, D. (2017). Reading effectively across the disciplines (READ): A strategy to improve student success. InSight: A Journal of Scholarly Teaching, 30(1), 30-50.

Callahan, C. M., Moon, T. R., Oh, S., Azano, A. P., \& Hailey, E. P. (2015). Documenting the effects of an integrated curricular/instructional model for gifted students. American Educational Research Journal, 52(1), 137-167. https://doi.org/10.3102/0002831214549448

Callaway, R. F. (2015). A correlational study of teacher efficacy and culturally responsive teaching techniques in a southeastern urban school district. Journal of Organizational \& Educational Leadership, 2(2), 1-27. https://files.eric.ed.gov/fulltext/EJ1144813.pdf

Cantrell, S. C., Almasi, J. F., Carter, J. C., \& Rintamaa, M. (2016). Supplemental reading strategy instruction for adolescents: A randomized trial and follow-up study. Journal of Educational Research, 109(1), 7-26. https://doi.org/10.1080/00220671.2014.917258

Center for Comprehensive School Reform and Achievement. (2008). Gifted and talented students at risk for underachievement. https://files.eric.ed.gov/fulltext/ED502904.pdf

Chametzky, B. (2014). Andragogy and engagement in online learning: Tenets and solutions. Creative Education, 5(1), 813-821. https://doi.org/10.4236/ce.2014.510095

Chen, S., \& Herron, S. S. (2014). Going against the grain: Should differentiated instruction be a normal component of professional development. International Journal of Technology in Teaching and Learning, 10(1), 14-34.

Cleaver, S. (2008). Smart and bored: Are we failing our achievers? Instructor, 117(5), 29-32.

Coleman, J. S., Schneider, B., Plank., Schiller, K. S., Shouse, R., Wang, H., \& Lee, S. (2018). Redesigning American education. Routledge Taylor \& Francis. 
Conklin, H. G. (2014). Toward more joyful learning: Integrating play into frameworks of middle grades teaching. American Education Research Journal, 51(6), 1227-1255. https://doi.org/10.3102/0002831214549451

Cook, D. (2005). The research we still are not doing: An agenda for the study of computer-based learning, Academic Medicine, 8o(6), 541-548. https://journals.lww.com/academicmedicine/Fulltext/2005/06000/The Research We Still Are Not Doing An Agenda for.5.aspx

Darrow, A. (2016). Every Student Succeeds Act (ESSA): What it means for students with disabilities and music educators. General Music Today, 3o(1), 41-44. https://doi.org/10.1177/1048371316658327

Day, R. (2015). Extending extensive reading. Reading in a Foreign Language, 27(2), 294-301. http://nflrc.hawaii.edu/rfl/October2015/discussions/day.pdf

Dimitriadis, C. (2016). Gifted programs cannot be successful without gifted research and theory: Evidence from practice with gifted students of mathematics. Journal for the Education of the Gifted, 39(3), 221-236. https://doi-org.ezp.waldenulibrary.org/10.1177/0162353216657185

Dimitriadou, C., Nari, E., \& Palaiologou, N. (2012). E-Learning teacher training courses for differentiated instruction in multicultural classrooms: Reflections upon the participants' experiences. Journal of Educational Technology, 9(3), 14-26. https://files.eric.ed.gov/fulltext/EJ1102151.pdf

Doubet, K., \& Hockett, J. (2016). Icing on the cake. Educational Leadership, 74(2), 16-20.

Doubet, K., \& Hockett, J. (2017). Discourse as civil discourse: With the help of these instructional strategies, educators can teach students to turn controversy into conversation. Educational Leadership, 75(3), $56-60$.

Dreilinger, D. (2019, November 26). Up to 3.6 million students should be labeled gifted; but aren't. The Hechinger Report. https://hechingerreport.org/up-to-3-6-million-students-should-be-labeled-giftedbut-arent/

Duquette, C. (2016). A study of inclusive practices. Journal of Research in Special Educational Needs, 16(1), 111-115. https://doi.org/10.1111/1471-3802.12132

Esparza, J., Shumow, L., \& Schmidt, J. A. (2014). Growth mindset of gifted seventh grade students in science. NCSSSMST Journal, 6-13. https://files.eric.ed.gov/fulltext/EJ1045824.pdf

Farrington, C. A., Roderick, M., Allensworth, E., Nagaoka, J., Keyes, T. S., Johnson, D.W., \& Beechum, N. O. (2012). Teaching adolescents to become learners. The role of noncognitive factors in shaping school performance: A critical literature review. https://consortium.uchicago.edu/sites/default/files/201810/Noncognitive\%20Report_o.pdf

Fenty, N., Mulcahy, C., \& Washburn, E. (2015). Effects of computer-assisted and teacher-led fluency instruction on students at risk for reading failure. Learning Disabilities: A Contemporary Journal, 12(2), 141-156.

Finn, C. E., \& Wright, B. L. (2015, October 20). America's smart kids left behind [Blog post]. http://www.educationnext.org/americas-smart-kids-left-behind/\#f

Fisher, D., \& Frey, N. (2016). Power plan. Journal of Staff Development, 37(2), 12-17. https://learningforward.org/docs/default-source/jsd-april-2016/power-plan-april16.pdf

Flink, F. (2017). Adapting self-selected reading passages for college-level developmental reading courses. Reading Improvement, 54(3), 87-93. 
Goddard, Y., Goddard, R., \& Kim, M. (2015). School instructional climate and student achievement: An examination of group norms of differentiated instruction. American Journal of Education, 122(1), 111-131. https://doi.org/10.1086/683293

González, J. D. (2017). A model for the strategic use of metacognitive reading comprehension strategies. Profile Issues in Teachers' Professional Development, 19(2), 187-201. https://doi.org/10.15446/profile.v19n2.58826

Gray, K. (2012). From the bottom to the top. Essence, 43(5), 114-119.

Hanushek, E., \& Woessmann, L. (2012). Economic benefit of educational reform in the European union. CESifo Economic Studies, 58(1), 73-109. https://doi.org/10.1093/cesifo/ifro32

Hobbs, M., \& Dofs, K. (2017). Self-access centre and autonomous learning management: Where are we now and where are we going? SiSAL Journal, 8(2), 88-101.

http://sisaljournal.org/archives/jun17/shanshan

Jennings, J. (2012). Reflections on a half-century of schoolreform: Why have we fallen short and where do we go from here? Center on Education Policy. https://www.cepdc.org/displayDocument.cfm?DocumentID $=392$

Jennings, J., \& Lauen, D. (2016). Accountability, inequality, and achievement: The effects of the No Child Left Behind Act on multiple measures of student learning. Journal of the Social Science, 2(5), 220-241. https://doi.org/10.7758/RSF.2016.2.5.11

Jesus, O. N. (2012). Can differentiated instruction provide success for all learners? National Teacher Education Journal, 5(3), 5-11.

Joseph, S., Thomas, M., Simonette, G., \& Ramsock, L. (2013). The impact of differentiated instruction in a teacher education setting: Successes and challenges. International Journal of Higher Education, 2(3), 28-40.

Karaduman, G. B. (2013). Underachievement in gifted students. International Journal of New Trends in Education and Their Implications, 4(4), 165-172.

Keyes, S. E., Jacobs, J., Bornhorst, R., Gibson, L. J., \& Vostal, B. R. (2017). Supplemental computerized reading instruction in oral reading fluency and its generalizable effects on at-risk urban second graders. Reading Improvement, 54(1), 9-18.

Klapwijk, N. M. (2015). $\mathrm{EMC}^{2}$ = comprehension: A reading strategy instruction framework for all teachers. South African Journal of Education, 35(1), 994.

Laverick, D. M. (2014). Supporting striving readers through technology-based instruction. Reading Improvement, 51(1), 11-19.

Leal, F. (2015, July 30). Survey: Most high school students feel unprepared for college and careers. EdSource. edsource.org/2015/survey-most-high-school-students-feel-unprepared-for-college-careers/83752

Little, C. A., McCoach, B. D., \& Reis, S. M. (2014). Effects of differentiated reading instruction on student achievement in middle school. Journal of Advanced Academics, 25(4) 384-402. https://doi.org/10.1177/1932202X14549250

Maslow, A. H. (1943). Theory of human motivation. Psychological Review, 50, 370-396. https://doi.org/10.1.1.318.2317

McCarty, W., Crow, S.R., Mims, G.A., Potthoff, D.E., \& Harvey, J.S. (2016). Renewing teaching practices: differentiated instruction in the college classroom. Journal of Curriculum, Teaching, Learning and Leadership in Education, 1(1), 35-44. 
McElhone, D. (2015). Using stems and supported inquiry to help an elementary teacher move toward dialogic reading instruction. Journal of Classroom Interaction, 50(2), 156-171.

McGuinn, R. (2015). School the state: ESEA and the evolution of the U.S. Department of Education. Journal of the Social Sciences, 1(3), 77-94. https://doi.org/10.7758/RSF.2015.1.3.04

McLean, E. A. (2012). How the accelerated reading program supports the comprehension development of struggling readers. Education and Human Development Master's Theses. http://digitalcommons.brockport.edu/ehd theses/157

McLeod, S. A. (2017). Maslow's hierarchy of needs. www.simplypsychology.org/maslow.html

Möller, K. J. \& Ferguson, L. (2015). Apps in literature-based classroom instruction: integrating reading and response through traditional and digital media. Journal Of Children's Literature, 41(1), 54-60.

Monks, F. (2014). No Child Left Behind and the impact of Kurt Heller's work. Journal for the Education of the Young Scientist and Giftedness, 2(1), 33-39. https://doi.org/10.17478/JEYSG.201429011

National Assessment of Education Progress (NAEP). (2015). The nation's report card. https://www.nationsreportcard.gov

National Assessment of Education Progress (NAEP). (2017). The nation's report card. https://www.nationsreportcard.gov

National Center for Education Statistics. (2019). The condition of education, 2019: Reading performance. https://nces.ed.gov/programs/coe/pdf/coe_cnb.pdf

Ness, M. (2017). “Is that how I really sound?” Using iPads for fluency practice. Reading Teacher, 7o(5), 611-615.

Nguyen, M. (2013). Peer tutoring as a strategy to promote academic success. https://childandfamilypolicy.duke.edu/pdfs/schoolresearch/2012 PolicyBriefs/Nguyen Policy Brie f.pdf

Nichols, W. D., Rupley, W. H., Blair, T. R, \& Wood, K. D. (2008). Vocabulary strategies for linguistically diverse learners. Middle School Journal, 39(3), 65-69. https://doi.org/10.1080/00940771

Nicolae, M. (2014). Teachers' beliefs as the differentiated instruction starting point: Research basis. Social and Behavioral Sciences, 128(1), 426-431. https://doi.org/10.1016/j.sbspro.2014.03.182

Ochoa, M. A., \& Ramírez, M. S. (2016). Strategy based instruction facilitated by technologies to enhance reading comprehension. Journal of Language Teaching \& Research, 7(4), 655-664.

https://doi.org/10.17507/jltr.0704.04

Pascual, R. M., \& Guevara, R. L. (2017). Experiments and pilot study evaluating the performance of reading miscue detector and automated reading tutor for Filipino: A children's speech technology for improving literacy. Science Diliman, 29(1), 5-36.

Pimentel, S. (2013). College and career readiness standards for adult education (Prepared for U.S. Department of Education, Office of Vocational and Adult Education). MPR Associates. https://lincs.ed.gov/publications/pdf/CCRStandardsAdultEd.pdf

Podgurski, M. (2016). Theorists and Techniques: connection education theories to Lamaze teaching techniques. Journal of Perinatal Education, 25(1), 9-17. https://doi.org/10.1891/1058-1243.25.1.9

Pratt, T. (2017). The open access dilemma: How can community colleges better serve underprepared students? Education Next, 17(4), 34-41. http://educationnext.org/open-access-dilemma-communitycollege-better-server-underprepared-students/ 
Rapp, D. N., van den Broek, P., McMaster, K. L., Kendeou, P., \& Espin, C. A. (2007). Higher-order comprehension processes in struggling readers: A perspective for research and intervention. Scientific Studies of Reading, 11(4), 289-312. https://doi.org/10.1080/10888430701530417

Ritchey, K. D., Palombo, K., Silverman, R. D., \& Speece, D. L. (2017). Effects of an informational text reading comprehension intervention for fifth-grade students. Learning Disability Quarterly, 4O(2), 68-80.

Saldana, L. B. (2013). What do good readers do on the computer? Reading Teacher, 66(7), 553. https://doi.org/10.1002/TRTR.1158

Sanders, M. (2017). Principled practice: Welcoming diversity. A journey in three steps towards encouragement of the heart. Journal of World Federation of Associations of Teacher Education Research and Studies 1(1), 35-53.

Schatz, M. (2015). Toward one of the leading education-based economies? Investigating aims, strategies, and practices of Finland's education export landscape. Journal of Studies in International Education, 19(4), 327-340. https://doi.org/10.1177/1028315315572897

Siam, K., \& Al-Natour, M. (2016). Teacher's differentiated instruction practices and implementation challenges for learning disabilities in Jordan. International Education Studies, 9(12), 167-181.

Siegle, D., \& McCoach, D. B. (2018). Underachievement and the gifted child. In S. I. Pfeiffer, E. ShaunessyDedrick, \& M. Foley-Nicpon (Eds.), APA handbooks in psychology. APA handbook of giftedness and talent (pp. 559-573). American Psychological Association. https://doi.org/10.1037/0000038-036

Sparks, S. D. (2019, April). Four ways schools help or hinder gifted students. Education Week. https://www.edweek.org/ew/articles/2019/04/17/gifted-education-four-studies-you-shouldknow.html

Stack, S. (2015) Learning outcomes in an online vs traditional course. International Journal for the Scholarship of Teaching and Learning, 9(1), 1-15. https://doi.org/10.20429/ijsotl.2015.090105

Tatter, G. (2015). Tennessee rolls out sweeping literacy initiatives amid stagnant reading scores. https://www.chalkbeat.org/author/gtatter/page/9/

Tennessee Department of Education. (2017). 2017 Annual statistical report. https://www.tn.gov/education/data/department-reports/2017-annual-statistical-report.html

Tennessee Department of Education. (2018). 2018 Annual statistical report https://www.tn.gov/education/data/department-reports/2018-annual-statistical-report.html

Thompson, T. F., Andrews, P. G., Jackson, C. S., \& Reagin, M. (2010). Who are my students and why does it matter? Using service-learning to teach children impacted by poverty. Middle School Journal, 41(4), 52-61. https://doi.org/10.1080/00940771.2010.11461732

Tomlinson, C. (2015). Teaching for excellence in academically diverse classrooms. Society, 52(3) 203-209. https://doi.org/10.1007/s12115-015-9888-0

U.S. Department of Education. (2011). Title I: Improving the academic achievement of the disadvantaged. http://www2.ed.gov/policy/elsec/leg/esea02/pg1.html\#sec1001

VanTassel-Baska, J., \& Stambaugh, T. (2012). Challenges and possibilities for serving gifted learners in the regular classroom. Theory Into Practice, 44(3), 211-217.

Van Wyk, M. M. (2017). E-portfolio as empowering tool to enhance students' self-directed learning in a teacher education course. South African Journal of Higher Education, 31(3), 274-291. https://doi.org/10.20853.5/31-3-834 
Wadmany, R., \& Klichko, S. (2014). The significance of digital pedagogy: Teachers' perceptions and the factors influencing their abilities as digital pedagogues. Journal of Educational Technology, 11(3), 22-33. https://files.eric.ed.gov/fulltext/EJ1098588.pdf

Wan, S. W. (2016). Hong Kong in-service teacher readiness for differentiated instruction. Journal of the World Federation of Associations of Teacher Education, 1(1), 54-73. https://www.worldfate.org/docpdf/journal 01-01.pdf\#page $=55$

Watts-Taffe, S., Laster, B., Broach, L., Marinak, B., Connor, C., \& Walker, D. (2012). Differentiated instruction: Making informed teacher decisions. The Reading Teacher, 66(4), 303-314. https://doi.org/10.1002/TRTR.01126

Whitten, C., Labby, S., \& Sullivan, S. (2016). The impact of pleasure reading on academic success. Journal of Multidisciplinary Graduate Research, 2(4), 48-64.

Wijekumar, K., Meyer, B. J. F., \& Lei, P. (2017). Web-based text structure strategy instruction improves seventh graders' content area reading comprehension. Journal of Educational Psychology, 109(6), 741-760. https://doi.org/10.1037/eduoooo168

Wilhelm, J. D. \& Wilhelm, P. J. (2010). Inquiring minds learn to read, write, and think: Reaching all learners through inquiry. Middle School Journal, 4O(5), 39-46.

Yacapsin, M. S. (2013). Faith: A new component with differentiated instruction. Christian Perspectives in education, 6(1), 2-18.

Yang, X., Li-Jen, K., Ji, X., \& McTigue, E. (2018). A critical examination of the relationship among research, theory, and practice: Technology and reading instruction. Computers \& Education, 125, 62-73. https://doi.org/10.1016/j.compedu.2018.03.009

Yot-Domínguez, C., \& Marcelo, C. (2017). University students' self-regulated learning using digital technologies. International Journal of Educational Technology in Higher Education, 14, 1-18. https://doi.org/10.1186/s41239-017-0076-8

Yuen, M., Chan, S., Chan, C., Fung, D. C. L., Cheung, W. M., Kwan, T., \& Leung, F. K. S. (2016). Differentiation in key learning areas for gifted students in regular classes: A project for primary school teachers in Hong Kong. Gifted Education International, 34(1), 36-46.

https://doi.org/10.1177/0261429416649047

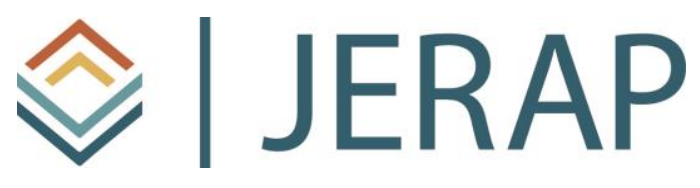

The Journal of Educational Research and Practice is a peerreviewed journal that provides a forum for studies and dialogue about developments and change in the field of education and learning. The journal includes research and related content that examine current relevant educational issues and processes. The aim is to provide readers with knowledge and with strategies to use that knowledge in educational or learning environments. JERAP focuses on education at all levels and in any setting, and includes peer-reviewed research reports, commentaries, book reviews, interviews of prominent individuals, and reports about educational practice. The journal is sponsored by the Richard W. Riley College of Education and Leadership at Walden University, and publication in JERAP is always free to authors and readers. 